\title{
Contributions of ludic care in nursing to chemical detoxification due to the use of crack cocaine
}

\author{
Contribuições do cuidado lúdico em enfermagem \\ na desintoxicação química devido ao uso de crack \\ Contribuciones del cuidado lúdico en enfermería en la \\ desintoxicación química debido al uso de crack
}

\author{
Paola Aparecida Pavanatto \\ Maria Helena Gehlen ${ }^{b}$ \\ Silomar Ilhac \\ Claudia Zamberlan ${ }^{\mathrm{d}}$ \\ Rosiane Filipin Rangele \\ Elisabeta Albertina Nietsche ${ }^{f}$
}

\section{ABSTRACT}

Objective: to understand the contributions of ludic care in nursing by stimulating the acceptance of chemical detoxification from crack on the perception of people in the detoxification process.

Methods: an exploratory, descriptive study with a qualitative approach, performed with five people hospitalized for chemical detoxification from crack, from March to July 2013 in a chemical detox unit of a midsize hospital in the central region of Rio Grande do Sul. Data was collected using a semi-structured interview and was subjected to content analysis.

Results: Two categories emerged: Ludic care in nursing as a stimulus to the acceptance of chemical detoxification; Ludic care in nursing in the promotion for healthy living after chemical detoxification.

Conclusion: Iudic care in nursing proved to enhance the acceptance of chemical detoxification from crack in the reality investigated. Keywords: Crack cocaine. Inactivation, metabolic. Hospitalization. Health education. Nursing care.

\section{RESUMO}

Objetivo: conhecer as contribuições do cuidado lúdico em enfermagem no estímulo à aceitação da desintoxicação química pelo uso do crack na percepção das pessoas em processo de desintoxicação.

Métodos: estudo exploratório, descritivo, de abordagem qualitativa, realizado com cinco pessoas internadas para desintoxicação química do crack, no período de março a julho de 2013, em uma unidade de desintoxicação química de um hospital de médio porte da região central do Rio Grande do Sul. Os dados foram coletados por meio de uma entrevista semiestruturada e foram submetidos à análise de conteúdo.

Resultados: emergiram duas categorias: 0 cuidado lúdico em enfermagem como um estímulo à aceitação da desintoxicação química; Cuidado lúdico em enfermagem na promoção para o viver saudável após a desintoxicação química.

Conclusão: 0 cuidado lúdico em enfermagem mostrou-se potencializador para a aceitação da desintoxicação química do crack na realidade investigada.

Palavras-chave: Cocaína, crack. Inativação metabólica. Hospitalização. Educação em saúde. Cuidados de enfermagem.

\section{RESUMEN}

Objetivo: conocer las contribuciones del cuidado lúdico en enfermería en el estímulo a la aceptación de la desintoxicación química por el uso del crack en la percepción de las personas en ese proceso.

Métodos: estudio exploratorio, descriptivo de abordaje cualitativo realizado con cinco personas hospitalizadas para desintoxicación química, en el período de marzo a julio de 2013, en una unidad de desintoxicación química de un hospital de mediano porte de la región central de Rio Grande do Sur. Los datos fueron recolectados por una entrevista semiestructurada y sometidos a análisis de contenidos.

Resultados: surgieron dos categorías: El cuidado lúdico en enfermería, como un estímulo a la aceptación y como la promoción para el vivir saludable después de la desintoxicación química.

Conclusión: el cuidado lúdico en enfermería, se mostró potenciador a la aceptación de la desintoxicación del crack en la realidad investigada.

Palabras clave: Cocaína crack. Inactivación metabólica. Hospitalización. Educación en salud. Atención de enfermería.

D0l: $\quad$ http://dx.doi.org/10.1590/19831447.2015.02.48736

\footnotetext{
Nurse, graduated from Centro Universitário Franciscano. Santa Maria, Rio Grande do Sul (RS), Brazil.

${ }^{b}$ Nurse. Master in Education. Professor at Centro Universitário Franciscano. Santa Maria, RS, Brazil.

'Nurse. Master in Nursing. Doctoral student at the Graduate Program in Nursing (PPGEnf) of the Federal University of Rio Grande (FURG). Rio Grande, RS, Brazil. ${ }^{a}$ Nurse. PhD in Nursing. Professor at Centro Universitário Franciscano. Santa Maria, RS, Brazil.

e Nurse. Master in Nursing. Professor at Centro Universitário Franciscano. Santa Maria, RS, Brazil.

f Nurse. PhD in Nursing. Professor at the Federal University of Santa Maria (UFSM). Santa Maria, RS, Brazil.
} 


\section{口INTRODUCTION}

The contemporary reality, experienced worldwide, has placed new challenges on nursing care, mainly on the way certain issues are usually addressed, especially in the field of health education. This occurs, among other factors, due to the fact that the subjects on whom nursing professionals intervene present themselves as complex, requiring that these efforts avoid reductionist simplifications.

This is the case with the issue of alcohol and other drugs, like crack, that unveils the development of nursing care, considering care of the biological, cognitive and educational needs, as well as the emotions and feelings of people with needs arising from the use of $\operatorname{crack}^{(1)}$. The first reported use of this substance in Brazil was in 1989, in São Paulo. In the 90s, the use of drugs increased worldwide, but crack remained restricted to marginalized groups. Currently, this affects various social classes, it his highly addictive and widely associated with crime ${ }^{(2)}$.

Historically, the issue of abuse and/or dependence on alcohol and other drugs has been approached from a predominantly psychiatric and pharmacological perspective, from the perspective of a positivist and biomedical paradigm. However, the social, psychological, educational, cognitive, economic, cultural and political implications are evident, and should be considered in the overall understanding of this pointed question ${ }^{(2)}$.

People with needs arising from the use of crack are sometimes hospitalized against their will to undergo chemical detoxification and drug treatment. Medication treatment is fundamental, but it must be one of the dimensions of clinical care. This care needs to include reception, from the arrival of the person at the hospital unit until after discharge, through substitutive strategies that guarantee rights, the promotion of independence and the exercise of citizenship in the pursuit of progressive social inclusion ${ }^{(3)}$.

Combining clinical care with educational needs during chemical detox can assist in the treatment and care of the human being's cognitive, neurological motor, nutritional, emotional, and spiritual deficits. Nursing professionals, when opting for ludic care, can promote and encourage people with needs arising from the use of crack to perceive themselves as singular social subjects, allowing them to reflect on the best way to live healthy within their context and choices ${ }^{(1)}$.

Healthy living can be understood as a complex phenomenon, spurred by experiences of order and disorder, searching for continuous, individual, familiar and social self-organization ${ }^{(4-5)}$. Ludic care in nursing at the chemical detoxification unit studied was carried out in order to enhance the acceptance and the link between those who provide care and those who receive care, and raise awareness about the importance of the detoxification process. It can be regarded as a technology that enhances human attributes such as listening, dialogue, creativity, respect and sensitivity ${ }^{(3)}$.

Although we have knowledge about illicit drugs in Brazil, there are still difficulties in the effective care of people hospitalized for the use of these substances, as well as the guiding of public policies for health education in monitoring those who have already gone through the chemical detoxification process and returned to where they reside Some national studies have been developed with people with needs arising from the use of crack, in order to understand the specifics of treatment, ${ }^{(6)}$ developing strategies to address the risks of using these substances, ${ }^{(7)}$ among other goals.

The investment in international research on the subject is also evident, examining the effects of crack on the activation of the prefrontal cortex in women infected with $\mathrm{HIV}^{\left({ }^{(8)} \text {. }\right.}$ Assessment of the efficacy of medication on reducing the desire and the amount of cocaine and/or crack used, and increased adherence to treatment for addiction ${ }^{(9)}$.

Therefore, we can perceive the interest of researchers from different countries of the subject at hand, however, there is a gap of knowledge about ludic care in nursing, combined with pharmacological clinical treatment, in the care of these people, reinforcing the importance of this study with regards to the construction of a knowledge to be added to what already exists on the theme. Ludic care in nursing can offer people in a detox situation the stimulus for healthy living, assisting in addressing one of the biggest public health problems in Brazil.

Based on these considerations, the question is: What is the perception of people in the chemical detoxification process from the use of crack regarding ludic care in nursing to stimulate acceptance of chemical detoxification for healthy living? The study aimed to: understand the contribution of ludic care in nursing to stimulate acceptance of the use of chemical detoxification from crack on the perception of people in the detoxification process.

\section{METHODOLOGY}

Exploratory, descriptive, qualitative approach, performed at a chemical detox unit of a midsize hospital in Rio Grande do Sul (RS). The unit has 25 beds for the Unified Health System (SUS): one children's bed (under 10 years), four beds for adolescents (14-18 years old and under 14 years old with a companion only), 10 beds for women and 10 for adult men (above 19 years old). 
People aged 14-18 years who were undergoing chemical detoxification in the period of data collection were invited to participate this study, for convenience. People were excluded if they were in clinical conditions of hypersexualization, risk of suicide/murder, escape, or had clinical diseases such as tuberculosis. Five people met the inclusion criteria, forming the corpus of this study. The choice for adolescents occurred because they were the ones who were in the unit at the time that activities started.

At the beginning of March 2013, a visit to the unit was made, where a dialogue was carried out between the professionals and people in the detoxification process, in order to survey the cognitive, motor, metabolic, ventilatory and social difficulties of the adolescents. Among the difficulties non-acceptance of the detoxification process stood out.

From this, recreational activities were operationalized and developed once a week during the period from March to June 2013, each lasting an average of two hours. Those who participated in the activities included four graduates from the nursing course and a teaching nurse, responsible for the project, as well as five service professionals: a psychologist, a nurse technician, a psychiatrist, a social worker and an educator.

Such activities took place through discussion groups, competitions, therapeutic workshops using posters, serial albums, objects and playful artifacts (dolls, colorful clothes and props). In all activities, the people who were in the detoxification process received information about crack, had the opportunity to get their questions answered by professionals and reported their experiences with the needs arising from the use of drugs to the group.

To assess the contribution of the activities, the investigators returned to the unit and conducted semi-structured interviews with an average duration of one hour, using open-ended questions, which were scheduled ahead of time with the study participants. The interviews were not recorded in audio but recorded by one of the graduate students, while the other carried out the questioning. After, the answers were read back to the participant for validation of the data.

The data was submitted to content analysis, taking into account the three steps of the method. Initially, there was a thorough reading of the data, then the organization of the material and formulation of hypotheses. As a result, exploration of the material was done, encoding the raw data. Finally, the data was interpreted and broken up into themes, according to the meanings attributed ${ }^{(10)}$.

The ethical and legal precepts were considered, in accordance with Resolution 196/96(11). Participants and par- ents/guardians signed the Informed Consent Form (ICF), in duplicate, one remaining with the participant and the other, with the researchers. Deponents were identified by the letter $\mathrm{E}$ (Interviewee) followed by a numerical figure according to the interview order (E1, E2 ... (E5). The research project was approved by the local Research Ethics Committee, under number 072.2010.2.

\section{RESULTS AND DISCUSSION}

Of the five subjects who participated in this study, three were male and two were females, 14 to 18 years old. They had all needs arising from use of crack and other associated drugs and had already previously been admitted for detoxification. This data corroborates other studies that describe adolescence and young adulthood as the main drug trial period ${ }^{(6-12)}$. Studies have shown a higher prevalence for drug use among males ${ }^{(6-13)}$, a fact that is in line with the data from this study.

From an analysis of the data, two categories emerged: Ludic care nursing as a stimulator of the acceptance of chemical detoxification; Ludic care in nursing in promoting healthy living after chemical detoxification.

\section{Ludic nursing care as a stimulus to the acceptance of chemical detoxification}

Care through recreational activities involved a moment of welcome, connection, respect for people with needs arising from the use of crack that were hospitalized, signifying an important step to them for acceptance of the condition to undergo chemical detoxification.

[...] it represented progress in the treatment, it helped to interact with other people, because I am a repressed person, it is hard for me to make friends, and the activities helped with the interaction [...] (E1)

Playfulness is an internal experience of the person who has the experience, aiming to promote rehabilitation and reintegration into society. It presents itself as an opportunity to transform the hospital into a comforting space, not only through the use of a game, television and radio, but also through smiles, touch and dialogue $e^{(1)}$

We considered that ludic care in nursing helped with the acceptance of chemical detoxification, in the reality investigated, enhanced the welcoming of people with needs arising from the use of crack and they then perceived their value as human beings, in a participatory manner, in their care and treatment: 
[...] Yes, it certainly makes me happy, because through the activities we get to talk, interact, learn about the lives of the other people, get to know each other, get along, see their differences, their virtues. It's great, because if it was not for these activities, I would be the same outside, that same person that doesn't even speak to my mother. When I was home, I would watch her (mother) go into her room so that I could leave mine [...] (E1)

[...] I thought it was good, I took full advantage because, after all, the only thing I had was your activities, which were educational. Games that we didn't even care about before, we value now, out there we thought that they were uncool and kid stuff, but in here they are entertaining, fun and supportive [...] (E2)

The use of crack generates abandonment of work, study or interest in anything other than the substance. There may be a deterioration of family relationships, with domestic violence and frequent abandonment of homes, increasing the stigmatization of people with needs arising from the use of crack, exacerbating their social exclusion ${ }^{(6)}$

Among the psychological consequences of the use of crack is easy dependence after initial use, causing great discomfort during withdrawal, which can cause depression, anxiety and aggression towards family and others ${ }^{(6)}$. Ludic care also helps in this regard, since it can influence the process of awareness and acceptance of chemical detoxification, it allows the person to rebuild/prepare conflicts in a symbolic way.

We inferred that ludic care in nursing at the detoxification unit valued the human being, so that he or she could accept that this moment of hospitalization was necessary in his or her life:

[...] of course, here I am, listening, I care, the activities make our day better. And here inside I have a different vision of my life out there, only now I realize how easy it is, I just try to $[. .].(E 3)$

[...] this was the first hospitalization where I have been treated as an equal, I don't get dirty looks, you, at such a young age, made me see life in a way that is so clear, so simple, it was a learning experience; your activities were great, I learned quite a lot. It was nice to interact, meet the staff, I realized that there are good people [...] (E4)

Playfulness has the ability to engage and enthuse people, allowing them to feel motivated. It mobilizes mental outlooks, helping the physical and mental aspects, since it triggers and activates psychological and neurological functions, stimulating thought. Thus, these activities involve the dimensions of the affective, motor and cognitive personality, since the human being who is involved with the ludic activity is also the being that acts, feels, thinks, learns and develops ${ }^{(14)}$. One can perceive their interest so that the activities have continued:

[...] I would like that, because I have another two months here, besides being cool, making the time go faster, it's good for us to be distracted, I feel valued. Not only as a patient but as a person. (E2)

Certainly, it motivates us, help during hospitalization, makes it easy to get here, the twenty-one days go faster [...] (E3)

[...] I would like to have the ludic activity, it's great to occupy my head, not thinking about the drug, it's a great way to pass the time, it distracts and delights us [...] (E4)

We can see that stimulating the acceptance of the chemical detoxification condition as one of the dimensions for care in this context, requires, from the nursing/ health professional, an approach that values the essence and the life history of hospitalized persons. Thus, it is understood that they can consciously choose which healthy living comes closest to their contextual reality.

To this end, it becomes necessary for the professionals who serve people with needs arising from the use of crack, especially nurses, act as agent of social change and lead the situations of everyday life, being qualified for complete and humane care ${ }^{(15)}$.

\section{Ludic care in nursing in the promotion for healthy living after chemical detoxification}

Assisting in the detoxification process through recreation complies with educational management, since it combines the opportunity to deepen people's reflection with needs arising from the use of crack, for healthy living:

[...] a form of affection, a push to start again, outside my life was meaningless, it was upside down, I had no desire to live, depression drove me to drink more and then use the damn rock (crack), I went around aimlessly, thinking I could do anything. In here I treat myself and I can still distract myself, it is very good [...] (E3)

In the report, it is possible to can see the disorder experienced by a person with needs arising from using crack 
and the association of it with other drugs. In a study conducted in southern Brazil, researchers showed that most people started using drugs through legal drugs like alcohol and tobacco, and evolved to the use of illegal ones, including $\operatorname{crack}^{(16)}$.

In the reports, below, there is evidence of the perception about dependence on crack as a disease and the contribution of ludic care in nursing to assist in treatment:

[...] it helps because we feel like people again, we are in search of a cure for a disease, here are welcomed, we are treated as people, and outside we are discriminated against. People that use discriminate against themselves[...] (E2)

Crack is a difficult disease to cure [...] but inside I have realized that this is possible. Outside it is difficult because there is a lot of discrimination [...] (E5)

It is also possible to observe the discrimination that people with needs arising from the use of crack and other drugs experience from society as a whole, as well as self-discrimination. Similar results were shown in other studies ${ }^{(7-17) .}$ To be discriminated against and mistreated, people with needs arising from the use of crack, increasingly enter the world of $\mathrm{drugs}^{(7)}$. The following notes the difficulty keeping away from drugs after the detoxification period:

I would love to be the person I am inside, outside, but out there I cannot be, due to depression. At that point / wavered and started using again; the day before I was hospitalized l used crack [...] (E1)

Similar data was seen in other studies ${ }^{(15,18)}$. This fact can be attributed, among other factors, to the instant euphoria triggered by the use of this drug that motivates the desire for a new episode of use, establishing an intimate and almost irrepressible relationship of dependence between the person and the drug ${ }^{(18)}$.

It was found that recreation in detoxification connects questions about the promotion of healthy living so that the human being, in its uniqueness, can consciously, during hospitalization, start the search for a new way of living with other attitudes and new habits:

[...] it will help a lot, since, out there, I'll stop everything, I will change my life; I will have a clear head, I will not spend time with those guys I hung around with [...], now I realize that the drug is bad for my body and even my mind, it left me bewildered, aimless, I abandoned everything for it.
Now I want to regain what I have lost, including my children, because only I know how I got here [...] (E4)

By using crack, toxic substances that cause lung lesions are absorbed; destruction of brain cells; muscle degeneration, severe insomnia, elevated levels of aluminum in the blood, burns on the lips, nose and fingers ${ }^{(9.19)}$. Therefore, it is possible to see that ludic care, combined with clinical pharmacological and psychiatric management, is relevant with regard to the improvement of the physical aspect, since the interconnection between these approaches to care/treatment provides an understanding of the problems that the substance causes to the body.

For this reason, ludic care is characterized by interventions with the potential for greater effectiveness in the detoxification acceptance process. It contributes to a break in the hospitalization routine, and improves acceptance of the disease. This practice can be performed with various types of people in different hospitalization situations; thus contributing to an innovative practice within the field of nursing ${ }^{(20)}$.

Ludic care for the research subjects enhanced the understanding that you can be happy without the use of crack also being of great importance to the closeness, reintegration and reconstruction of family ties.

[...] all the activities that you did were always different, it was very good. I will live healthy for my children, I will even try to pass on the games to them, the competitions, making the most of them, because I want to be a real mother $[\ldots](E 2)$

We can observe that ludic care in nursing helps them to understand how people can again be inserted in society and reorganize their lives. Therefore, this care is characterized as an innovative strategy to be implemented in the health service, in different contexts, since they allow the individuality of the person to be rescued, and enable humanized and integrated care(20).

\section{CONCLUSION}

Ludic care in nursing has been shown to enhance acceptance of chemical detoxification from the use of crack in the reality investigated. It allowed us to explore the potential of the people in the study, highlighting their qualities, which sometimes were left out as a result of using crack. The recovery of self-esteem was stimulated, as was the new search values, and a different life during and after the detoxification period. 
As for the fragility/limitations of this research, we highlight the lack of studies using ludic care in the chemical detoxification scenario, thus hindering the comparison of the data from this research to others. As for positive points, we highlight the openness of the people who agreed to participate. Given the results, we suggest the routine implementation of ludic care by nursing/health professionals, in the reality investigated.

The study presents a contribution to the practice of nursing/healthcare regarding extended care to people with needs arising from the use of crack, it points out the ludic activities as a way to improve care for these people since they have proven to be effective in aiding treatment and, more specifically, acceptance of the detoxification process in the reality investigated. It contributes to science, whereas the results presented in this care model, can instigate other researchers to use it in their research related to crack as well as other themes and health research scenarios.

\section{$\square$ REFERENCES}

1. Beuter M, Cordeiro FR, Quinhones SMW, Lima MGR, Brondani CM. 0 teatro como estratégia lúdica no cuidado ao doente hospitalizado. Rev Enferm UFPE. 2010;4(1):401-4.

2. Siqueira DF, Moreschi C, Backes DS, Lunardi VL, Lunardi Filho WD, Dalcin CB. Repercussões do uso de crack no cotidiano familiar. Cogitare Enferm. 2012;17(2):248-54.

3. Ministério da Saúde (BR). Portaria no 3.088, de 23 de dezembro de 2011. Institui a Rede de Atenção Psicossocial para pessoas com sofrimento ou transtorno mental e com necessidades decorrentes do uso de crack, álcool e outras drogas, no âmbito do Sistema Único de Saúde (SUS). Diário Oficial da União [da] República Federativa do Brasil. 2011 dez 30;148(251 Seção 1):59-61.

4. Backes MTS, Backes DS, Erdmann AL, Buscher A. The meaning of healthy living in a socially vulnerable community in southern Brazil. Acta Paul Enferm. 2012;25(2):190-6.

5. Grupo de Estudos e Pesquisa em Empreendedorismo Social da Enfermagem e Saúde. Validação de um conceito de enfermagem à luz da complexidade. Conceito discutido e validado no grupo de pesquisa, 2011.
6. Oliveira EN, Nogueira NF, Marinho MP, Nogueira DL, Rocha NNV, Duarte SR. Caracterização dos usuários de crack atendidos no CAPS álcool e outras drogas. Rev Enferm UFPE. 2012;6(9):2093-102.

7. Teixeira AA, Kantorski LP, Corrêa ACL, Ferreira RZ, Ferreira GB, Santos MOE. Crack users: developing strategies to face the risks of the consumption. J Rev Fundam Care. 2015;7(2):2393-2404.

8. Meyer VJ, Little DM, Fitzgerald DA, Sundermann EE, Rubin LH, Martin EM, et al. Crack cocaine use impairs anterior cingulate and prefrontal cortex function in women with HIV infection. J Neurovirol. 2014;20(4):352-61

9. Dieckmann LH, Ramos AC, Silva EA, Justo LP, Sabioni P, Frade IF, et al. Effects of biperiden on the treatment of cocaine/crack addiction: a randomized, double-blind, placebo-controlled trial. Eur Neuropsychopharmacol. 2014;24(8):1196202.

10. Bardin L. Análise de conteúdo. Lisboa: Edições 70; 2011.

11. Ministério da Saúde (BR). Conselho Nacional de Saúde. Resolução no 196, de 10 de outubro de 1996. Diretrizes e normas regulamentadoras de pesquisas envolvendo seres humanos. Diário Oficial [da] República Federativa do Brasil. 1996 out.16;134(201 Seção 1):21082-5.

12. Zeitoune RCG, Ferreira VS, Silveira HS, Domingos AM, Maia AC. 0 conhecimento de adolescentes sobre drogas lícitas e ilícitas: uma contribuição para a enfermagem comunitária. Esc Anna Nery. 2012;16(1):57-63.

13. Botti NCL, Machado JSA, Tameirão FV. Perfil sociodemográfico e padrão do uso de crack entre usuários em tratamento no Centro de Atenção Psicossocial. Estud Pesqui Psicol. 2014;14(1):290-303.

14. Teixeira CEJ. A Ludicidade na escola. São Paulo: Loyola; 1995.

15. Gabatz RIB, Schmidt AL, Terra MG, Padoin SMM, Silva AA, Lacchini AJB. Perception of crack users in relation to use and treatment. Rev Gaúcha Enferm. 2013;34(1):140-6.

16. Seleghim MR, Marangoni SR, Marcon SS, Oliveira MLF. Family ties of crack cocaine users cared for in a psychiatric emergency department. Rev Latino-Am Enfermagem. 2011;19(5):1163-70.

17. Romanini M, Roso A. Midiatização do crack e estigmatização: corpos habitados por histórias e cicatrizes. Interface (Botucatu). 2014;18(49):363-76.

18. Silva Junior FJG, Monteiro CFS. The meanings of death and dying: the perspective of crack users. RevvLatino-Am Enfermagem. 2012;20(2)378-83.

19. Maraj S, Figueiredo VM, Lynn MSD. Cocaine and the heart. Clin Cardiol. 2010;33(5):264-9.

20. Moura CC, Resck ZMR, Dázio EMR. Atividades lúdicas realizadas com pacientes portadores de neoplasia internados em hospital geral. Rev Rene. 2012;13(3):667-76

\section{Author's address:}

Silomar Ilha

Rua Coronel Niederauer, 265/201, bloco 2, Noal

97020-160 Santa Maria - RS

E-mail: silo_sm@hotmail.com
Received: 15.07.2014

Approved: 19.05.2015 